\title{
SEJARAH LINGKUNGAN SEBAGAI PENDIDIKAN PENGURANGAN RESIKO BENCANA DI KABUPATEN KETAPANG KALIMANTAN BARAT
}

\author{
Basuki Wibowo, Agus Dediansyah
}

\author{
Dosen Pendidikan Sejarah IKIP PGRI Pontianak, email: \\ basuki.khatulistiwa23@gmail.com
}

\begin{abstract}
The learning of environmental history developed in Ketapang District can be utilized as an education for natural disaster risk reduction. This study aims to determine and explore the history of the environment and the potential contained in oral history to be made as a disaster risk reduction education in Ketapang Regency, West Kalimantan. This study uses qualitative research methods with a form of embedded case study strategies. Data sources used are informants, places and events, and documents. Data collection techniques using direct observation techniques, in-depth interviews, and document studies. The sampling technique used is purposive sampling. Data validity uses triangulation and data analysis techniques use interactive analysis techniques. The Potential of Environmental History as Disaster Risk Reduction Education (PPRB) in Ketapang Regency, West Kalimantan is very large. Utilization of history known to the community from its environment will form its own memory. Disaster Risk Reduction Education (PPRB) is oriented to the development of a community and is active, creative, innovative, effective. Through learning the history of the environment will form the character of people who have environmental concerns so that the risk of natural disasters due to environmental damage can be overcome and minimized.
\end{abstract}

Keywords: Environmental history, Disaster Risk Reduction

\begin{abstract}
ABSTRAK
Pembelajaran sejarah lingkungan yang di kembangkan di Kabupaten Ketapang dapat di manfaatkan sebagai pendidikan pengurangan resiko bencana alam. Penelitian ini bertujuan untuk mengetahui dan menggali sejarah lingkungan dan potensi yang terkandung dalam sejarah lisan untuk di jadikan sebagai pendidikan pengurangan risiko bencana di Kabupaten Ketapang Kalimantan Barat. Penelitian ini menggunakan metode penelitian kualitatif dengan bentuk strategi studi kasus terpancang. Sumber data yang digunakan yaitu informan, tempat dan peristiwa, dan dokumen. Teknik pengumpulan data menggunakan teknik observasi langsung, wawancara mendalam, dan studi dokumen. Teknik cuplikan (sampling) yang digunakan bersifat purposive sampling. Validitas data menggunakan triangulasi dan teknik analisa data menggunakan teknik analisis interaktif. Potensi Sejarah Lingkungan sebagai Pendidikan Pengurangan Risiko Bencana (PPRB) di Kabupaten Ketapang Kalimantan Barat sangat besar. Pemanfaatan sejarah yang di ketahui
\end{abstract}


masyarakat dari lingkungannya akan membentuk memori tersendiri. Pendidikan Pengurangan Risiko Bencana (PPRB) berorientasi pada perkembangan sebuah masyarakat dan bersifat aktif, kreatif, inovatif, efektif. Melalui pembelajaran sejarah lingkungan akan terbentuk karakter masyarakat yang memiliki kepedulian lingkungan sehingga risiko bencana alam akibat kerusakan lingkungan bisa di atasi dan di minimalisasi.

Kata Kunci: Sejarah lingkungan, Pengurangan Risiko Bencana

\section{PENDAHULUAN}

Bencana alam tidak dapat di predikasi kedatangannya. Banjir dan kebakaran hutan lahan (Karhutla) merupakan bencana alam tahunan yang terjadi di hampir semua wilayah Provinsi Kalimantan Barat. Pengetahuan dan pemahaman masyarakat akan ciri dan dampak dari bencana alam masih sangat minim. Korban bencana alam, baik korban fisik maupun korban jiwa masih banyak terjadi walaupun bencana alam di Provinsi Kalimantan Barat selalu terjadi dari tahun ke tahun. Pengetahuan akan lingkungan tempat tinggal menjadi sangat penting agar masyarakat mampu membaca tanda tanda datangnya bencana alam.

Kesiapan masyarakat dalam menghadapi bencana sangat di butuhkan guna mengurangi adanya korban. Sosialisasi pentingnya pengetahuan tentang kesiapsiagaan bencana menjadi tanggung jawab bersama antara pemerintah dan seluruh elemen masyarakat. Undang Undang No.24/2007 tentang penanggulangan bencana di susun pemerintah sebagai landasan sosialisasi Pengurangan Risiko Bencana (PRB).Pemerintah melalui Bappenas juga menyusun buku Rencana Aksi Nasional Pengurangan Resiko Bencana (RAN PRB), dan membentuk Badan Penaggulangan Bencana Daerah(BPBD) yang tersebar di tingkat propinsi sampai Kabupaten. Masyarakat harus mendukung program pemerintah dengan cara, membentuk komunitas komunitas siaga bencana ataupun dengan memanfaatkan kearifan lokal yang mereka miliki.Keterlibatan masyarakat dalam usaha penanganan bencana telah di teliti oleh Weichselgartner (2015), Desfandi (2014), dan Maryani (2014). Weichselgartner meneliti tentang usaha mengurangi resiko bencana melalui managemen kesiapan masyarakat dalam menghadapi bencana. Desfandi dan Maryani dalam penelitian menekankan pentingnya kearifan lokal masyarakat dalam memitigasi bencana dan aplikasinya sebagai sumber pembelajaran. 
Pengetahuan masyarakat tentang sejarah lingkungan di sekitar tempat tinggalnya sangat di perlukan sebagai upaya Pendidikan Pengurangan Risiko Bencana (PPRB). Mempelajari sejarah lingkungannya secara tidak langsung masyarakat sudah melakukan upaya mempelajari kejadian alam kejadian alam yang telah lalu sehingga dapat memprediksi adanya kemungkinan apa yang akan terjadi di masa yang akan datang. Kajian sejarah lingkungan akan mengarahkan pada di temukannya kearifan lokal yang mengarah pada bagaimana masyarakat pada jaman dahulu menyikapi datangnya bencana alam. Kearifan lokal sendiri mengarah pada cara yang dikembangkan masyarakat berdasarkan pada pemahaman akan lingkungan setempat, yang di wariskan secara turun-temurun (Galla, 2001). Kearifan lokal masyarakat Kabupaten Ketapang Kalimantan Barat dalam mempelajari perkembangan alam dengan cara melihat, mengamati dan membandingkan suatu kejadian dari masa ke masa.

Mempelajari sejarah lingkungan di Kabupaten Ketapang, Kalimantan Barat tidak lepas dari mempelajari interaksi manusia dengan lingkungan dari masa ke masa. Perubahan lingkungan baik akibat ulah manusia maupun faktor yang lainnya akan berdampak pada relasi manusia dengan lingkungan dan hobby. Kabupaten Ketapang merupakan daerah rawan bencana, terutama dampak dari kerusakan hutan. Kerusakan hutan di kabupaten Ketapang memicu banjir dan kebakaran hutan. Hutan yang gundul memicu tumbuh ilalang yang rawan terbakar pada musim kemarau. Kebakaran lahan dan hutan di Kabupaten Ketapang terjadi sejak tahun tahun 1968. Dampak dari terbakarnya hutan di Kabupaten Ketapang sangat kompleks. Dampak kebakaran hutan yang sekarang banyak di rasakan oleh masyarakat adalah kerusakan hutan yang memicu banjir.

Penelitian pembelajaran sejarah lingkungan sebagai upaya pengurangan risiko bencana di Kabupaten Ketapang Kalimantan Barat menjadi penting karena masyarakat di Kabupaten Ketapang belum dapat memanfaatkan pengetahuan yang mereka miliki sebagai salah satu upaya Pendidikan Pengurangan Risiko Bencana. Pembelajaran Sejarah lingkungan di harapkan mampu mengedukasi masyarakat tentang pentingnya menjaga lingkungan dari kerusakan guna meniminalisir datangnya bencana alam. Dengan mempelajari sejarah lingkungan maka di harapkan masyarakat mampu memaknai gejala alam sehingga dapat mengambil tindakan tindakan dalam merespon gejala alam sehingga masyarakat siap apabila bencana alam datang. 


\section{METODE PENELITIAN}

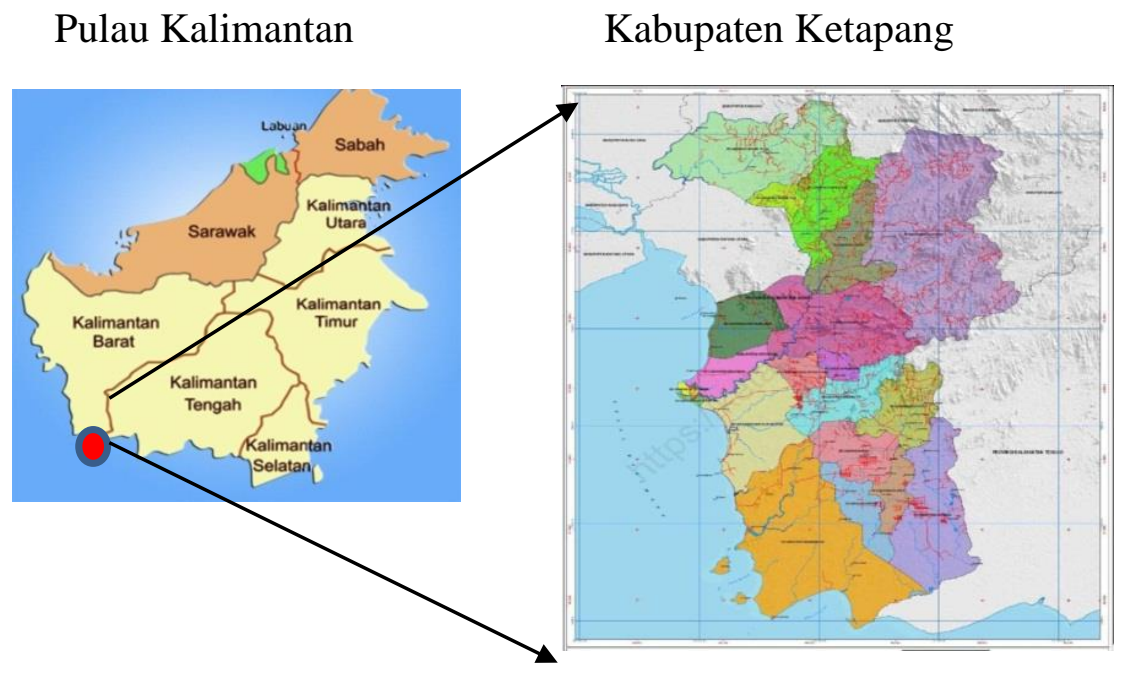

Penelitian menggunakan metode penelitian deskriptif dengan pendekatan kualitatif. Lokasi penelitiandapat di lihat pada gambar diatas. Pengumpulan data dilakukan melalui observasi dan wawancara. Pengamatan dalam kegiatan observasi dilakukan pada: daerah rawan banjir dan kerusakan hutan hutan di Kabupaten Ketapang. Kegiatan wawancara dilakukan kepada para narasumber dan informan, yaitu tokoh masyarakat, budayawan, pemerhati sejarah, manggala agni dan warga masyarakat Melayu di Ketapang. Informan kunci dipilih secara snowballing dimulai dari kepala adat hingga warga masyarakat yang mengetahui tentang topik tersebut. Informasi yang dikumpulkan meliputi (a) konsep hutan adat, (b) konsep pelestarian hutan, (c) bentuk dan cara masyarakat mencegah atau mengurangi risiko bencana alam. Data dan informasi yang telah dikumpulkan diolah dengan menggunakan analisis deskriptif kualitatif. Data yang dianalisis meliputi kebakaran hutan, banjir, pengetahuan masyarakat tentang upaya pelestarian hutan, pengetahuan masyarakat tentang sejarah di lingkungannya dan pengurangan resiko bencana terutama terkait kebakaran hutan. Validitas data menggunakan triangulasi dan teknik analisa data menggunakan teknik analisis interaktif.

\section{HASIL DAN PEMBAHASAN}

Kajian tentang lingkungan dalam pembelajaran masih sangat sedikit. Sejarah lingkungan di Indonesia belum berkembang karena selama ini kajian 
sejarah lebih pada sosial, ekonomi dan politik. Sejarah lingkungan kurang populer untuk menjadi kajian kajian yang diteliti dan di bahas sejarawan, padahal sangat relevan dengan perkembangan zaman. Permasalahan lingkungan di lihat dari sudut pandang sejarah belakangan ini penting untuk di kaji. Bencana alam yang terjadi terutama yang di sebabkan oleh manusia merupakan salah satu kajian yang harus di gali terutama di wilayah Provinsi Kalimantan Barat yang rawan akan bencana banjir dan kebakaran hutan lahan.

Kajian sejarah lingkungan masih baru. Sejarah lingkungan mengajak manusia bisa mengetahui lingkungan berdasarkan perspektif skala, sehingga kita mengetahui kerusakan lingkungan akan berdampak pada bencana yang besar. Pada tingkat pelajar, pembelajaran sejarah lingkungan memberi pemahaman siswa tentang bagaimana relasi manusia dengan alam dan permasalahan per masalah lingkungan yang ada termasuk adanya potensi bencana di daerah tempat tinggal. Sejarah lingkungan mempelajari bagaimana hubungan timbal balik manusia degan hewan dan lingkungan biotik lainnya. Kajian sejarah lingkungan melihat keterlibatan dan peran manusia dalam proses munculnya permasalahan lingkungan serta tanggapan untuk mitigasi bencana (Nawiyanto, 2013).

Sejarah lingkungan di Kalimantan Barat kebanyakan membahas permasalahan lingkungan. permasalahan lingkungan baru muncul di Indonesia belakangan ini. kasus permasalahan lahan dan hutan baru muncul setelah orde baru mengeluarkan revolusi hijau. Kebijakan pemerintahan Orde Baru tentang pemanfaatan hutan di Kalimantan Barat yang meliputi pembukaan, program transmigrasi, dan pemberian konsesi Hak Pengusahaan Hutan (HPH) berdampak pada kehidupan masyarakat Ketapang. Hak Pengusahaan Hutan (HPH) berdampak pada banyaknya sumber daya hutan berupa kayu alam yang habis.

Pemanfaatan hutan yang tidak ramah lingkungan akan berdampak negatif terhadap kelangsungan hidup manusia. Dampak negatif tersebut antara lain berupa kenaikan laju erosi, kenaikan aliran permukaan serta penurunan fungsi hidrologis hutan sebagai pengendali banjir, kekeringan dan kebakaran hutan. Kebakaran hutan berdampak pada kabut asap yang melanda pulau Kalimantan bahkan sampai ke negara Malaysia, Brunai Darussalam, dan Singapura pada tahun 1991.

Kerusakan hutan berdampak pada bencana tahunan yang selalu ada di Kabupaten Ketapang. Berdasarkan catatan Walhi, pada bulan Januari sampai Oktober 2012 terdapat sejumlah 1757 titik api yang bersumber dari pembakaran 
hutan yang dilakukan oleh 77 perusahaan yang menggarap 938.791 Ha lahan (KR, Maret 2013: 8). Seringnya kebakaran hutan di Kabupaten Ketapang terjadi sejak tahun tahun 1968. Sejak tahun 1968 hingga akhir tahun 1990 berdasarkan catatan Dinas Kehutanan Provinsi Kalimantan Barat, setidaknya telah berdiri 75 perusahaan pemegang konsesi HPH dengan luas ijin keseluruhan mencapai 46,60\% dari total luas wilayah Kabupaten Ketapang (Alqadrie, 1994). Berdasarkan Catatan BPBD Ketapang dari tahun 2010-2015 Kecamatan Sungai Laur merupakan wilayah yang sering kena dampak banjir dengan 12 kejadian. Kebakaran hutan sering terjadi di Kecamatan Matan Hilir Selatan.

Dampak dari terbakarnya hutan di Kabupaten Ketapang sangat komplek. Kabut asap yang tebal berdampak pada jarak pandang dan kesehatan pernapasan. Keterbatasan jarak pandang maka banyak transportasi baik air maupun udara yang tidak mau ambil resiko untuk beroperasi. Terputusnya transportasi air (sungai dan Laut), udara dan darat berakibat pada terganggunya distribusi barang dan tergangunya perekonomian. Dampak kebakaran hutan yang sekarang banyak di rasakan oleh masyarakat adalah kerusakan hutan yang memicu banjir. Banjir di Ketapang terjadi akibat dari akumulasi per masalah lingkungan dari hilir ke hulu. Per masalah dari hulu berupa berkurangnya lahan hutan sebagai serapan air. Pengaliran air yang terdiri dari sungai dan anak sungai sudah tidak mampu menampung akumulasi air hujan sehingga meluap. Permasalahan di hilir adalah banyaknya sungai yang tertutup sedimentasi akibat dari hutan gundul. Kawasan rawan banjir di daerah hilir merupakan yang berbatasan langsung dengan laut atau sungai dengan kelerengan kurang dari dua persen atau dua hingga delapan persen. Bencana alam hidrometeorologi seperti banjir, tanah longsor, kekeringan, merupakan bencana alam yang paling banyak di Indonesia. Hampir 85\% bencana alam di Indonesia merupakan bencana alam hidrometeorologi (Setyowati, 2013:12).

\section{Potensi Sejarah Lingkungan sebagai Pendidikan Pengurangan Risiko Bencana (PPRB) di Kabupaten Ketapang Kalimantan Barat}

Pendidikan pengurangan risiko bencana (PPRB), menurut UN-ISDR, adalah "sebuah pembelajaran bersama dan bersifat interaktif di tengah masyarakat dan lembaga-lembaga lainnya dengan cakupan pendidikan yang lebih luas daripada pendidikan formal di sekolah dan universitas dalam upaya mempersiapkan masyarakat tanggap bencana. PPRB adalah usaha sadar dan terencana dalam proses pembelajaran untuk pemberdayaan peserta didik dalam 
upaya untuk pengurangan risiko bencana dan membangun budaya aman serta tangguh terhadap bencana (Subagio, 2009).

Sejarah lingkungan yang berkembang dalam masyarakat di wilayah Kabupaten Ketapang kebanyakan bercerita tetang hubungan manusia dengan alam. Hubungan manusia dengan lingkungan yang tidak seimbang di mana masyarakat cenderung mengeksploitasi hasil alam tanpa reboisasi menyebabkan munculnya bencana alam. Bencana banjir dan kebakaran hutan menjadi bencana tahunan.

Sejarah lingkungan memiliki potensi untuk pengurangan resiko bencana. Pengetahuan akan lingkungan yang dimiliki seseorang akan menjadi kunci untuk kesiapsiagaan dalam menghadapi risiko bencana. Pengetahuan yang dimiliki seseorang akan mempengaruhi sikap untuk siap dan siaga dalam mengantisipasi bencana terutama bagi mereka yang bertempat tinggal di daerah rawan bencana.

Pengetahuan masyarakat Ketapang yang di dapat dari cerita yang di wariskan secara turun temurun menghasilkan ingatan yang kuat akan sejarah lingkungannya. Tujuan pembelajaran sejarah lingkungan adalah mengenalkan lingkungan tempat tinggal kepada masyarakat sekitar. Hal ini sesuai dengan tujuan pendidikan pengurangan risiko bencana. Subagyo (2009) menjelaskan bahwa tujuan PPRB mencakup 5 hal, yaitu; 1) Menumbuhkan sikap peduli terhadap risiko bencana bagi masyarakat, 2) Mengembangkan pemahaman risiko bencana, kerentanan sosial, dan kerentanan fisik, 3)Meningkatkan pengetahuan dan keterampilan masyarakat untuk melakukan pencegahan terhadap potensi bencana, pengetahuan pengurangan risiko bencana, dan adaptasi dengan risiko bencana, 4) Mengembangkan kesiapan masyarakat dalam usaha mendukung pembangunan kembali infrastruktur dan semangat juang suatu komunitas korban bencana pada saat terjadi bencana dan mengurangi dampak akibat bencana, 5) Meningkatkan kemampuan untuk beradaptasi masyarakat terdampak bencana dengan perubahan besar dan mendadak pada lingkungannya (subagyo,2009).

Pengurangan risiko bencana bersifat berkelanjutan dan melibatkan partisipasi dari semua pihak. PPRB di Kabupaten Ketapang tidak hanya melibatkan pemerintah daerah dan anggota masyarakat saja. Pihak sekolah juga harus di libatkan. Pembelajaran sejarah lingkungan untuk PPRB membutuhkan 3 pilar penopang, yaitu guru, strategi pembelajaran dan aspek penunjang. Penguasaan guru terhadap peristiwa peristiwa bersejarah di lingkungan tempat tinggalnya akan akan berpengaruh terhadap kemampuan siswa untuk memahami 
persoalan yang ada di lingkungannya.Pembelajaran sejarah lingkungan bisa dikembangkan baik pada tingkat SMP melelui mata pelajaran IPS maupun SMU melalui mata pelajaran Sejarah. Penerapan model pembelajaran terpadu seperti pada mata pelajaran IPS, dapat meningkatkan pengetahuan kebencanaan siswa sehingga meningkatkan kesiapsiagaan siswa dalam menghadapi bencana alam yang sewaktu waktu terjadi (Pembriati, 2013:6).Tujuan pembelajaran sejarah lingkungan adalah mengenalkan lingkungan tempat tinggal kepada siswa. Pengenalan lingkungan, terutama dalam kajian sejarah membahas pola interaksi antara manusia dengan lingkungan tempat tinggalnya dari masa ke masa. Pengetahuan lingkungan yang di miliki oleh siswa hendaknya akan berdampak pada kepedualian siswa terhadap lingkungannya. Pendidikan karakter yang di canankan oleh pusat kurikulum pada tahun 2010 juga menekankan tentang pentingnya kepedulian siswa pada lingkungan.

Prioritas pengurangan risiko bencana di Kabupaten Ketapang harus berbasis pada lingkungan. Pemahaman sejarah lingkungan yang dilakukan sejak dini lewat dunia pendidikan akan membentuk karakter masyarakat yang sadar akan kebutuhan hidupnya terutama menjaga alam agar tidak terjadi bencana. Dalam melakukan PPRB perlu adanya pendekatan dan pengintegrasian dalam kegiatan belajar-mengajar yang berorientasi pada perkembangan anak dan kebutuhan anak serta bersifat aktif, kreatif, inovatif, efektif, dan menyenangkan (Subagio, 2009).

Sejarah lingkungan yang berkembang di masyarakat Kabupaten Ketapang sebelum bisa efektif untuk PPRB apabila tidak di dukung oleh masyarakat. Pendidikan pengurangan risiko bencana dengan sejarah lingkungan sebagai sumber belajar akan efektif apabila masyarakat memiliki kesadaran tidak hanya belajar sejarah tetapi juga mengaplikasikan dalam kehidupan sehari hari. Arismastuti (2011) menjelaskan bahwa pelaksanaannya PRB harus didukung oleh kelembagaan yang kuat serta mampu memanfaatkan pengetahuan, inovasi dan pendidikan untuk membangun kesadaran keselamatan diri dan ketahanan terhadap bencana pada semua tingkatan masyarakat.

\section{SIMPULAN}

Sejarah lingkungan di Kabupaten Ketapang, Kalimantan Barat kebanyakan membahas permasalahan lingkungan. Pemanfaatan hutan yang tidak ramah lingkungan akan berdampak negatif terhadap kelangsungan hidup manusia 
berupa bencana alam. Kebakaran hutan dan banjir merupakan bencana tahunan yang berdampak pada kehidupan ekonomi dan sosial masyarakat Ketapang. Sejak tahun 1991 hingga tahun 2019, kebakaran hutan berdampak pada kabut asap yang membuat udara tercemar hingga ke semua pulau Kalimantan bahkan sampai ke negara Malaysia, Brunai Darussalam, dan Singapura.

Potensi Sejarah Sejarah Lingkungan sebagai Pendidikan Pengurangan Risiko Bencana (PPRB) di Kabupaten Ketapang Kalimantan Barat sangat besar. Pemanfaatan sejarah yang di miliki masyarakat dari lingkungannya akan membentuk memori tersendiri. Pendidikan Pengurangan Risiko Bencana (PPRB) berorientasi pada perkembangan sebuah masyarakat dan bersifat aktif, kreatif, inovatif, efektif. Melalui pembelajaran sejarah lingkungan akan terbentuk karakter masyarakat yang memiliki kepedulian lingkungan sehingga risiko bencana alam akibat kerusakan lingkungan bisa di atasi dan di minimalisasi.

\section{DAFTAR PUSTAKA}

Alqadrie S.I. 1994. "Dampak Perusahaan Pemegang HPH dan Perkebunan terhadap Kehidupan Sosial Ekonomi dan Budaya Penduduk Setempat di Daerah Pedalaman Kalimantan Barat." dalam Florus P., Juweng S., Bamba J., Andasputra N. (ed.) Kebudayaan Dayak Aktualisasi dan Transformasi. Jakarta: PT Grasindo.

Arismastuti, Arandita. 2011. Tahapan Proses Komunikasi Fasilitator Dalam Sosialisasi Pengurangan Resiko Bencana. Journal Penanggulangan Bencana. 2 (2) $15-23$.

Desfandi, Mirza.2014. Urgensi Kurikulum Pendidikan Kebencanaan Berbasis Kearifan Lokal Di Indonesia. Jurnal Sosio Didaktika. Vol. 1, No. 2.

Galla, A. 2001. Guidebook for the Participation of Young People in Herttage Conservation. Brisbane: Hall and Jones Advertising.

Maryani, Enok, Ahmad Yani.2014. Kearifan Lokal Masyarakat Sunda Dalam Memitigasi Bencana Dan Aplikasinya Sebagai Sumber Pembelajaran IPS Berbasis Nilai. Jurnal Penelitian Pendidikan.14 (2)114-125.

Nawiyanto. 2013.Sejarah Lingkungan.Yogyakarta: Kurnia Kalam semesta 
Basuki Wibowo, Agus Dediansyah : Sejarah Lingkungan Sebagai Pendidikan Pengurangan

Pembriati, Erly Zohrian. 2013. Pengaruh model pembelajaran terpadu pada pengintegrasian Materi pengurangan risiko bencana dalam mata pelajaran IPS SMP terhadap pengetahuan dan kesiapsiagaan bencana. Jurnal Bumi Lestari.1 (1)1-8.

Setyowati, Dewi Liesnoor R. Sugiyanto.2013. Dampak Pembangunan Kawasan Industri Candi Pada Perilaku Banjir Kali Silandak Kota Semarang.FIS Forum Ilmu Sosial. 40 (2) 141-153.

Subagyo,Tatang. 2009. Modul Ajar Pengintegrasian Pengurangan Risiko Bencana Kebakaran, Bahan Pengayaan Bagi Guru SMP/MTs. Jakarta : Pusat Kurikulum Badan Penelitian dan Pengembangan Kementrian Nasional

Weichselgartner, Juergen. Patrick Pigeon. 2015. The Role of Knowledge in Disaster Risk Reduction. Int J Disaster Risk Sci 6:107-116 